\title{
Correction to: Oleic acid ameliorates palmitic acid induced hepatocellular lipotoxicity by inhibition of ER stress and pyroptosis
}

Xin Zeng, Min Zhu, Xiaohong Liu, Xuanmin Chen, Yujia Yuan, Lan Li, Jingping Liu, Yanrong Lu, Jingqiu Cheng and Younan Chen*

Correction to: Nutr Metab (2020) 17:11

https://doi.org/10.1186/s12986-020-0434-8

The original article [1] possessed a minor typo in first author, Xin Zeng's name which has since been corrected.

Published online: 12 March 2020

\section{Reference}

1. Zeng $X$, et al. Oleic acid ameliorates palmitic acid induced hepatocellular lipotoxicity by inhibition of ER stress and pyroptosis. Nutr Metab. 2020;17:11. https://doi.org/10.1186/s12986-020-0434-8.

* Correspondence: chenyounan@scu.edu.cn

Key Laboratory of Transplant Engineering and Immunology, NHFPC Regenerative Medicine Research Center, West China Hospital, Sichuan University, No. 1, Keyuan 4th Road, Gao Peng Street, Chengdu, Sichuan 610041, People's Republic of China

C C The Author(s). 2020 Open Access This article is licensed under a Creative Commons Attribution 4.0 International License, which permits use, sharing, adaptation, distribution and reproduction in any medium or format, as long as you give appropriate credit to the original author(s) and the source, provide a link to the Creative Commons licence, and indicate if changes were made. The images or other third party material in this article are included in the article's Creative Commons licence, unless indicated otherwise in a credit line to the material. If material is not included in the article's Creative Commons licence and your intended use is not permitted by statutory regulation or exceeds the permitted use, you will need to obtain permission directly from the copyright holder. To view a copy of this licence, visit http://creativecommons.org/licenses/by/4.0/ The Creative Commons Public Domain Dedication waiver (http://creativecommons.org/publicdomain/zero/1.0/) applies to the data made available in this article, unless otherwise stated in a credit line to the data. 